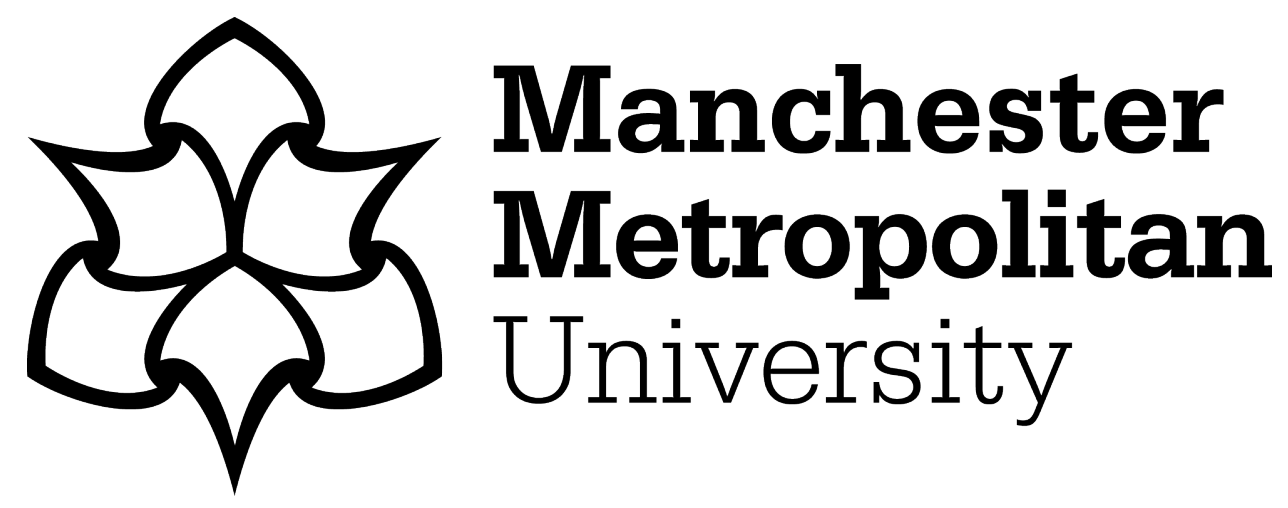

James, D and Colman, F (2017) 'Military Class: Hearts and Minds on the Domestic Screen'. In: Social class and television drama in contemporary Britain. Palgrave Macmillan, pp. 75-88. ISBN 113755505X

Downloaded from: https://e-space.mmu.ac.uk/618558/

Publisher: Palgrave Macmillan

Please cite the published version 


\section{Military Class: Hearts and Minds on the Domestic Screen.}

Felicity Colman and David James

Television frames the two World Wars of the first half of the twentieth century as defining social moments, with drama writers engaging with the material and experiential consequences of the very powerful polarizing national policies of these wars. Through the screen medium, the experience of war and all of its associated polarising and affective imaginaries offer the opportunity for what Geoff Eley has described as an "active archive of collective identification" (2001, p. 818). Just where and how forms of identification occur provide the grist of the plot and story. Convincing the enemy of its ideological authority was the ambition of the US military machine's mission during the Vietnam War. Named "Hearts and Minds", it is a sentiment which is used as a conceptual figure and a structuring device in many UK dramas. This sentiment - used as an tactic, informs the activities of militarism to deploy the rules of a class-based English system as a normative process that if obeyed, will restore order, and sometimes critically problematise this process whereby a military force attempts to win over a subjugated people.

This chapter examines the ways in which 'hearts and minds' are deployed through the English class system on the domestic screen as an axiom of nationalism, given form through the aesthetics of class. A number of television dramas use the narrative arcs of 'hearts and minds,' including Our Girl [BBC 2014, script Tony Grounds; dir. David Drury, Anthony Phillipson, Richard Senior], Soldier, Soldier (Central 1991-97), Downton Abbey, (ITV 1997 - 2015 script Julian Fellowes, Shelagh Stephenson and Tina Peplar, dir. Brian Percival et al), and War and Peace (BBC 2015, script Andrew Davies; dir. Tom Harper). The chapter focuses on Our Girl, to explore how the patriotic motivation of the military ethic of 'hearts and minds' facilitates class divisions between participants in the narratives. The chapter examines how this figure operates, creating a structuring principle across different dramas, and identifies where critical reception has noted this link between militarism and class as a focal point of the drama. Firstly, the chapter considers the notion of class in its English framing, and how it acts both as a marker of personal social position and in a wider sense as a symbol of national identity. In the United Kingdom of Our Girl this is a national identity that is largely controlled or mediated by the 
ruling class which is quintessentially the middle and (to a lesser extent) upper classes, whose ethnic majority is an Anglo-Saxon heritage. Secondly, the chapter examines, through the question of an aesthetics of class as depicted in Our Girl, if and how that gendered class system - as representative of the ruling government - is mapped out on the domestic screen in both reflective and problematizing ways. Finally, the chapter turns to the questions of ethics that the narrative of "hearts and minds" might generate, the conditions of militaristic action that are enabled in Our Girl, and other class based screen narratives. The chapter draws on and connects a number of theoretical models, in particular the work of David Cannadine (1998), to provide the framework for theorising institutional structures and their aesthetic strategies, as played out on screen.

\section{Our Girl}

Our Girl consisted of six one-hour episodes shown on BBC1 in 2014. This first series was developed out of a one-off drama, first shown in 2013. The original play follows the fortunes of Molly Dawes (played by Eastenders actress Lacey Turner), who comes from a large and chaotic white British family, living in the East End of London. On discovering that her boyfriend has cheated on her, and following a chance encounter with a persuasive recruitment officer, she enlists in the British Royal Army Medical Corps. The drama details her attempts to pass through the army induction process and escape what she describes as "my shitty little life just waiting to happen: middle aged me picking up toys and cans of lager while my tosspot boyfriend pisses on any dreams I might have had." Determined to escape this fate, (the fate in fact of her mother), Molly is shown as actively working to change her seemingly inevitable future. The pilot episode makes it clear that Molly and her working class family appear to live comfortably with their mixed race British neighbours. The dramatic conflict is given through Molly's gendered situation, which offers her a limited future of familial and relationship conflict.

The ensuing series is set a year later and with a largely different cast, and follows Molly as she qualifies as a medical technician, and after quickly receiving further combat training is almost immediately deployed to Helmand Province in Afghanistan. Whilst in Afghanistan, Molly's life continues to be constructed through relationship conflicts which increasingly make visible the power structures that control her life. Her family is now the army, her external community a territory troubled by ideological infiltration, and intimate relationship conflict is 
provided by way of a love triangle that develops between her former one night stand Private Dylan "Smurf" Smith (Iwan Rheon) and her commanding officer, Captain Charles James (Ben Aldridge).

The series has thus far not received positive critical responses. Two reviewers of the series noted that its style was akin to being a "recruitment video for the army" (Wollaston 2013; Bayliss 2013). The premise of the storylines suffer from under-development in terms of plausible character back stories, and the characters' motivations and desires remain largely unknown. What reviewers of the series have not explored is why it might be "compelling" viewing - as Sarah Crompton described it in 2013.

\section{National Class?}

David Cannadine in Class in Britain (1998) describes distinct class divisions that enable people to fit themselves into their 'place' within society according to their heredity, context and situation. In television dramas, indicators of class are readily conveyed through mise-en-scènic elements, situated by the actor's bodies and their relations within any given environment. Attending to the aspects of linguistic inflections, regional accents, vocabulary and speech patterns, as well as dress codes and forms of physical movement provide us with the material indicators of class structures. In Our Girl we are introduced to the situation of the two lead characters' relationship immediately through language-based class indicators. Their relational situation is identifiable through the conditions of their first meeting: a sexual encounter behind a fast food outlet. Upon their meeting again once deployed in Afghanistan, Dylan calls her "my Friday night behind the Indian takeaway in Guildford" and she addresses him by a nickname she has found post-encounter: "Smurf" (Ep. 1.1). Through language, they set the stage for the coming actions; all controlled by class-based units of behaviour that will govern and direct their distinct and collective actions in the business of being within a distinctively British war machine, where the hierarchical order of top-down power structures are maintained. While the sketchy narrative establishment of Molly's entry into the army in Our Girl, and subsequent scenes depict her participating in front line combat roles offer entry into the debate concerning the continuing sex discrimination against women in the army in the United Kingdom ${ }^{1}$, the principles of (British) order are continuously demonstrated in each storyline's trajectories towards equilibrium. The narrative propels itself through dramatic conflicts that take characters in and out of established hierarchical social orders, achieved simply through the structuring 
devices of class rules and implicit laws, which themselves explicitly reinforce gender divisions where those identifying as female are assigned a lesser social and political role, and are subject to culturally specific power controls.

In Our Girl, accents and vocabulary enrich the sparse dialogue. The narrative emphasis on Molly's class is given by her accent, and this has the effect of flattening the signifiers of her gendered "difference" within the various male-dominated systems that she enters. Molly's demotic London accent unambiguously marks her out as working class, just as the English Received Pronunciation accent of her work superior, Captain James, marks him out as middle class. The passion behind the words that Molly speaks, and the accompanying emotional register of the face of the actor Lacey Turner provide an intertextual credibility, so that the historical spectre of the determination of the working class society of Eastenders lends itself the to the back storylines in Our Girl. However, even with no knowledge of Turner's previous role in the London-based soap opera, the character conforms to what might be termed the 'Liza Doolittle' character trope. The aesthetics of the uniform contributes further details to all military dramas. Although the military uniform is used as a way of homogenising the people that comprise a particular group, standardisation occurs still at the level of rank, which in turn is often reflective of access to educational knowledge. Class is found in the technics of fabric, starch, and stitching of the uniform of all classes, obvious in the neat historical class divisions depicted in Downton Abbey, more subtle in contemporaneous depictions due to the proximity of representation for the viewer. In Our Girl, as a medic, Molly's technical field kit involves her always having a large handled pair of scissors visible in her chest pack; an object that marks her difference in uniform from the rest of her regiment. Worn by a woman, whose gender prevents her from taking part in the combat, only being involved at the level of repair, the scissors materially and semiotically interleave the historically-gendered images of seamstress and nurse into the combat field. These semiotic histories of the object, however un/intentional, signify a reminder of the principles of war that allows the killing of non-combatants; nurses and civilians. As Thomas Nagel argues (in response to American atrocities of war committed in Vietnam), the problem of using the argument of consequentialism to wage war; "that any means can in principle be justified if it leads to a sufficiently worthy end," is that it makes certain military actions defendable. Nagel points out that the military practice of waging war on civilian populations (such as he critiques with American intervention in the civilian population of Vietnam, and such is played on in the narrative of Western regiments in Afghanistan in Our Girl), means that activities that lead to the "deliberate killing of the 
harmless: civilians, prisoners of war, and medical personnel" cannot be justified, and are in fact acts of murder (Nagel 1979, pp. 57-8).

How then can we think about the British class system and, as a form of nationalism, how might its components be identified? Cannadine argues that rather than a stable and unchanging edifice, class is messy, difficult and malleable (1998, p.165). Drawing on the findings of sociologist Gordon Marshall, Cannadine concurs that "the 'class consciousness' of the majority of people is characterised by its complexity, ambivalence and occasional contradictions. It does not reflect a rigorously consistent interpretation of the world" (Marshall, et. al. in Cannadine 1998, p.165). Indeed, it is this very lack of consistency, which, as Cannadine argues, allows for the British public to understand the society in which they live in three essentially interchangeable ways. The first of these is the hierarchical system, starting with the monarchy at the top and ending with the marginal and disenfranchised at the bottom. Most people envisage themselves somewhere in between these two extremes in what Cannadine calls "an interlinked, finely layered and elaborately graded procession" (Cannadine 1998, p.164). The second model is the triadic model of (usually) upper, middle and lower classes and the thirdly is the dichotomous model that splits society into 'us' and 'them'. The former two categories perhaps speak more of finding and fitting in to one's place in society, whereas the latter model is somewhat more 'about' conflict and struggle. This is not however to claim that any of these models is particularly commendable as accurate or dependable descriptors of British society; as with most models they are grossly simplified versions of social reality as it is lived. British society is not (and never has been) a simple hierarchical society, nor has it been neatly divided into three graduated sections, or two oppositional sections. As Cannadine puts it, “... all of them are ignorant over-simplifications of the complexity of society. Yet they have remained remarkably enduring..." (Cannadine 1998, p.21). Indeed, it is the imprecise movement of divisions and superficiality that allows the British to carry these three models around with them, moving from model to model as needed. Cannadine also argues that there is a temporality implicit in these three models:

Hierarchy is generally about how society was; a backward looking picture of an ideal way of ordering the world, which needs to be preserved or restored. The three-stage model tends to be about how society is; especially when viewed, as is usual, from the vantage point of those in the middle. And the two-stage model is often concerned with how society might be; perhaps for good (if you are a would-be revolutionary), perhaps for ill (if you are not) (Cannadine 1998, p.170). 
Thus, as Cannadine makes clear, these multivalent notions of class in Britain are "as much about the history of ideas about society as about society itself' (Cannadine 1998, p.171). The three models of ranking individuals within society identified by Cannadine also map onto military structures of rank. Clearly, the hierarchical structure is directly analogous to military rank; a General outranks a Sergeant, and a Sergeant outranks a private. There is a highly organised system that exactly places an individual in a graded procession. Similarly, the triadic system of upper, middle and lower or working class is analogous to the three classes within the military; officers, NCOs and other ranks. This is not to suggest that these classifications necessarily directly map one to the other; it is possible to envisage working class people becoming officers and NCOs for instance. Nevertheless, just as it is useful as one of the models for looking at British society as a whole, it is similarly useful for mapping the narrative trajectories of forms and genres of the military drama.

The dichotomous 'us' and 'them' is a deceptively simple structure which the television scriptwriter uses to play with equilibrium and disequilibrium, thus propelling the narrative, but it can also be used to enable temporal pockets (of other ideas, people, places, events) to be inserted, later unfolded; problematizing any clear-cut difference, and serving as orienting points of reference in narratives. The 'us and them' provides one of the pleasures of televisual viewing; where gender, racial, and class-based differences provide an armchair demographic tour of duty. There are at least two ways of thinking about this structure in relation to the military class-based model. Firstly, and most obviously, there is 'us' and there is 'the enemy'. The enemy may actually be the opposing force; the ones trying to kill you before you kill them. However, in a non-combat sense, 'the enemy' may be either the other ranks or the officers, depending on where you are situated. In Our Girl, as with Downton Abbey, or the BBC's very British rendition of War and Peace, Cannadine's 'us and them' extends to the division of gender roles. Under United Kingdom legislation, Section 85(4) of the Sex Discrimination Act 1975 (SDA 75) the armed services are effectively exempted from the act which states that "it is unlawful for a person, in relation to employment by him [sic] at an establishment in Great Britain, to discriminate against a woman" (Sex Discrimination Act 1975). Therefore the division of gender roles is preserved in the armed forces in ways that would be illegal in other work places.

Cannadine notes with relation to class that "most people moved easily and effortlessly from one model to another, recasting their vision of British society to suit their particular purpose or perspective" (Cannadine, 1998, p.20). This can also be applied to the military 
setting, though in the military (unlike society as a whole), they exist in a highly structured and controlled environment. On the television screen then, the national political goals of either us or them becomes merged into us and them; where the attainment of the aspiration that is implicit in every interaction is delayed as long as script or budget or ratings dictate. Achieving a depiction of class on screen then, becomes bound to this notion of class-driven aspiration, and as the chapter now turns to examine, is realized by the performance and staging of the aesthetics of class by the collective identification (as Eley describes), created through televisual proximity.

\section{Class Aesthetics or the aesthetics of class?}

In Series 1 of Our Girl, Molly Dawes is posted to Afghanistan with an all male regiment. She is the nurse, although the historical female care-giver role is rejected by her tough East End non-nonsense approach, Molly's character demonstrates a practice of caring across a number of episodes. The model of class used in this series is very much akin to Cannadine's triadic model - with the addition of the hierarchies of the 'enemy' encountered on 'foreign' territories. The discrete episodes continue the class based structures when away and when at home, providing stability through change. The locations for each scene establish not only the sense of an 'otherness' (although the hierarchy of 'us and them' is always in play in quite simplistic terms), rather alterity is expressed in the series through the communication of difference. During a period of home leave in the episode "Changes" (1.3), East-Ender Dawes/Turner finds that home has been made strange through her experiences away, and during a visit to Wales realises that 'home' is constituted from different things. This device of inserting the British army/class situation into different physical location has also been picked up in the following series, set in Kenya, (BBC Media Centre, 2015). In this series, Turner is replaced by exCoronation Street actor Michelle Keegan, so that the 'common' southerner is replaced by the 'common' northerner. A by-word for working class, 'common-ness' has nothing to do with the roles these women perform in their working life, and their characters are able to display the sense of an "ethical self” that Bev Skeggs has described as where a working-class body displays some evidence of autonomy as opposed to an "enforced" subjectivity (Skeggs 2005, pp. 97374). However, in the narrative of Our Girl, the working-class bodies of women are always able to be commanded by their superior officers, or engaged as a site of inter-class generating drama, enabling a non-threatening position for the ruling culture. 
In each episode of the first series, Dawes repeatedly transgresses the class command hierarchy of the Royal Army. In her lapses from the hierarchical model - which range from misbehaviour in language and conduct, her role in the indiscretion with her superior, to disobedience in the field. The speech and actions depicted by the series realigns military class to a contextualizing needs-based temporal order. While Our Girl itself is flawed by a number of stylisation and production issues, it provides an interesting case study for thinking through how a framework of militarism, as an institutional machine at the service of a British class, and gender biased system is able to maintain itself by continually incorporate changes and potential subservience. It does so in spite of its clichéd plot and stylisation, often quite crudely depicted characters and characterisations, and its production style means that it engages in the glorification of military activity. The series follows Molly finding out how to exist, not just as a medic, but also as a woman cast in a role of carer within a male-dominated system, where "Yes, Sir" is often her only right of reply.

Further consideration of the aesthetics of class as a structuring device in screen narratives affords us the opportunity to re-examine the notion of aesthetics as a situating strategy. In Downton Abbey, Our Girl, and War and Peace, the scriptwriters want us to recognise class in terms of the tastes and decisions of the characters. There is an aesthetic of television class at play in these dramas, that is at once familiar, distasteful, and immediately historically identifiable. Used for political purposes, the indicators of class are given in nineteenth-century language of aesthetics; questions of the judgement of truth and of values such as good and evil continue to be employed in contemporary situations. But what makes Our Girl interesting is the ways in which that language is challenged and or overthrown. In the first episode of the series, "Time" (1.1), having been called 'our Doris' (a somewhat condescending slang term for women) by Captain James she complains to Smurf that "maybe I don't want that Rupert to like me" (a 'Rupert' being army slang for an incompetent upper class Officer). "He's a better person than you'll ever be" retorts Smurf, leaving her to find her own way to the women's quarters. Molly subsequently learns that Smurf's twin brother Geraint has been killed by the Taliban in a previous deployment, and that Captain James crawled two hundred metres on his belly in order to retrieve the body. Later in the episode, Smurf is shot by a sniper and it is Molly that volunteers to crawl on her belly through a minefield to save him. Despite being blown up by a landmine, (implausibly, she remains uninjured) Molly reaches the stricken Smurf and, disobeying James's direct orders, accompanies him on the helicopter winch because, as she tells James, "the tourniquet's not working. If I take my fist 
out of his groin he's going to bleed out". Thus, she matches James' heroism in every detail, indeed surpassing it since she has survived being blown up and saved Smurf's life. This does not, however, make her in any sense 'equal' to Captain James. In fact, having previously been 'sent to Coventry' by her squad [an English idiom that describes a group practice of ignoring or ostracizing someone for their deeds or differences], her 'reward' is promotion from a 'Doris' to 'one of the lads'. While Smurf does acknowledge that he owes her everything, there is no sense that he looks up to her, though he does now accept her as an equal. Clearly, there is an asymmetrical pattern of 'reward' here that is directly proportional to one's place in the military hierarchy; officers who display bravery do so because they are innately superior leaders of men (and women) whereas 'other ranks' who display courage are simply 'one of the lads'. This was institutionalised in the British armed forces in that, until 1993, different medals for the same acts of bravery were awarded to officers, NCOs and other ranks. This different way of regarding what are essentially the same actions dependent on one's class is, we would argue, also axiomatic of the way in which gender is treated in British military dramas entirely in terms of the established, yet paradoxically interchangeable hierarchical models. The extent to which Our Girl engages the gender factor to reflect any social changes in the established class hierarchy in Britain, given the changed historical context wherein the role of women in military activities is under legal review, remains a challenge to be taken up by scriptwriters.

The physical embodiment of 'hearts and minds' is actioned in the episode, Feelings (1.2), with the central theme of one the British Army's missions in Afghanistan, that of the facilitation of the education of girls, denied under the Taliban regime. Molly befriends an Afghan girl called Bashira (Becky Eggersglusz) in an Afghan village that her platoon visit, despite being warned by the rest of her squad that she is a 'dicker' (effectively a spy for the Taliban). Molly hands out pens to many of the children she encounters, which acts as both a visible metaphor for education and in a wider sense the 'civilising' of the 'savage' culture in which Molly - and the British Army - finds itself, since girls are not allowed to be educated in the Afghan culture as portrayed in Our Girl. The pen is indeed mightier than the sword when Bashira warns Molly of an impending attack by insurgents in the mountains, thereby saving the lives of British soldiers. Bashira is subsequently rigged with a suicide bomb by her Taliban father, but with Molly's help, is saved and whisked away to safety and (as we learn later) to receive an education. Education is a class marker in British society and can be read as Bashira's 'reward' for her providing intelligence on the insurgents. It is a simplistic yet effective rendering of the notion of 'hearts and minds,' yet the narrative of a liberation of the oppressed 
itself inserts a troubling problematic to the series. Although one of the affective points of the series, the ideological position behind the script compells and implicates the BBC viewer within the gender-imbalanced social and personal struggles that war brings, and the dangers it poses to any society interested in pursuing an ethics of equality, where clearly the class and gender bound power structures require a hierarchy to maintain their values. That this narrative is blatantly performed by Our Girl presents an historical index of late twentieth century class and gender, as Victoria Hesford has pointed out, capturing a very specific time in feminism (2008, p.170), which on-screen is where a supposed state-of-the-art military movement is shown to be in complete opposition to feminist requirements for non-oppressive regimes.

The narrative arc of Our Girl covers familiar tropes with regard to British military (or militaristic) drama, dating back to films made during the Second World War. Films such as The Bells Go Down (Dearden 1943) or The Way Ahead (Reed 1944), and later The Blue Lamp (Dearden 1950) use the narrative arc whereby a new recruit or recruits are at first outside the group (the fire brigade, army and police respectively), but are slowly assimilated into the group until they eventually become part of it and indeed help to replicate the group - in the case of The Bells Go Down and The Blue Lamp by taking the place of a fallen comrade. Molly therefore falls neatly into this model, especially given that Smurf later dies through injuries sustained in battle. The obvious difference with Our Girl is that the main protagonist is female, and although women in the British Army cannot take part in front line combat roles, a combat medical technician (CMT) is a soldier with medical training, and thus Molly can believably or justifiably join her comrades on patrol. Although this is a genuinely interesting twist on the old trope, it still ends in a continuation of the status quo. In class terms, this return to the status quo results in stasis; there is no way for Molly to transcend or progress past her class boundaries. Even her romantic affiliations offer her no respite from her social status. Just before his death, Smurf tells Molly he is leaving the army to become a mechanic with his uncle in Merthyr (a town in Wales). He offers to take Molly to Las Vegas as a best friend (rather than a romantic partner) because, as he says, "I know you've set your sights a bit above wife-of-mechanic-inMerthyr". With Smurf out of the picture, Molly's romance with Captain James is negated when he resigns his commission because he feels he has failed as an officer. On James' recommendation Molly stays on to mentor Afghan medics, performing her ethical but also socially enforced role as care practitioner. You can 'be the best' the programme seems to tell us, but you can't better yourself in class terms. 


\section{Conclusion: The ethics of Hearts and Minds}

After the coup d'etat which toppled Thatcher's premiership in 1990, John Major talked about "the classless society"2 - a place in which class would no longer be an issue. Seven years later in 1997, just before the election that would sweep Tony Blair's New Labour party to victory, John Prescott famously announced that "we're all middle class now"3. However, in a country that in 2016 still has unelected peers in Parliament, and that still has an honours system that ennobles civil servants, celebrities and politicians, neither Major nor Prescott's assertions stand up to scrutiny. If British society wanted to actually become the 'classless society' of Major's dreams, then as Cannadine points out (Cannadine, 1998, p.186), in order to end the hierarchical model of class, both hereditary and life peerages would need to be abolished, along with the House of Lords. The question of the monarchy would also need to be addressed, whether by abolition or a much reduced legitimacy; perhaps along the lines of the so-called 'bicycle monarchies' favoured in Scandinavia and Holland. As Cannadine also shrewdly observes, "the plebs, as well as the patricians, would have to be diminished and downsized, and the middle class correspondingly increased in number, size and self-regard" (Cannadine, 1998, p.187) in order for British society to abandon the triadic system. A reduction in inequality, both in monetary terms and in terms of privilege and life chances would perhaps help to diminish the separation between 'us' and 'them'. None of these things seem likely in the foreseeable future however; indeed institutions such as the education system, Parliament and the armed forces (to name but a few) only serve to perpetuate and replicate the status quo.

Dramas such as Our Girl perpetuate models of class that by their very nature divide British society, providing an active and dynamic register and archive of collective identification, through gender specific enforced modes of behaviour, languages and actions taken. In addition to setting up a number of romantic story lines typical of television mini series, Our Girl uses the class system framework for how the [military] 'mind' can be trained to overcome the civilian affects of the body, and perform the 'heart' of the matters at hand - and this is what provides the compelling nature of the series. Although it is not clear that the scriptwriter and producer are ultimately aware of the ideological imperative that are established (there are no self-reflexive moments provided in series one), the motivation to act; to take action, comes from the semiotic and material evidence given of the political class of each character's position in the narrative. As a military narrative, the story is propelled by the actions of the characters in reaction to collective events external to their situation, but which directly and dramatically impact upon their life conditions. As history has already determined the 
outcome of the larger story at hand, it is the particularity - or banality - of the details of each character's entanglement which makes the political situation come alive on screen. The class system implicit in the hierarchy of the armed services serve as a bastion of class difference that continues to be divisive of society at large.

\section{References}

Arendt, H. 1958. The Human Condition. Chicago: University of Chicago Press.

Arendt, H. and Beiner, R. 1982. Lectures on Kant's political philosophy. Chicago: University of Chicago Press.

Bayliss, M. 2013. Daily Express quote on Our Girl, collected in Broadcast. http://m.broadcastnow.co.uk/5053270.article [Accessed 17 Mar. 2016].

British Army 2016. British Army Structure - British Army Website. [online] Available at: http://www.army.mod.uk/structure/structure.aspx [Accessed 17 Mar. 2016].

BBC Media Centre 2015. "BBC - Michelle Keegan to lead new series of BBC One's Our Girl Media Centre. “ [online] Available at: http://www.bbc.co.uk/mediacentre/latestnews/2015/michelle-keegan-our-girl [Accessed 17 Mar. 2016].

Cannadine, D. 1998. Class in Britain. New Haven: Yale University Press. 
Crompton, S. 2013. "Sarah Crompton reviews Our Girl (BBC One), a single drama starring ex-EastEnders star Lacey Turner." [online] The Telegraph. Available at: http://www.telegraph.co.uk/culture/tvandradio/tv-and-radio-reviews/9949408/Our-Girl-BBCOne-review.html [Accessed 17 Mar. 2016].

Eley, G.. (2001). Finding the People's War: Film, British Collective Memory, and World War II. The American Historical Review, 106(3), 818-838. http://doi.org/10.2307/2692326

Beiner, R. and Nedelsky, J. (Eds.) 2001. Judgment, imagination, and politics: Themes from Kant and Arendt. Oxford, UK \& Lanham, Md.: Rowman \& Littlefield.

Hesford, V., 2008. "Securing a Future: Feminist Futures in a Time of War", in Feminist Time Against Nation Time. Hesford, V. and Diedrich, L. (Eds). Lanham, MD: Lexington Books, pp.169-184.

Kaplan, A. E. 2008. "Politics, Psyche and Feminine Time: Nancy Meckler's Sister, My Sister and Pratibha Parmar's Memsahib Rita”, in Feminist Time Against Nation Time. Hesford, V. and Diedrich, L. (Eds). Lanham, MD: Lexington Books, pp. 59-80.

Marshall, G., Newby, H., Rose, D. and Vogler, C., 1988. Social class in modern Britain. London: Unwin Hyman.

Ministry of Defence. 2014. "Review into the exclusion of women from ground close combat roles: terms of reference" Available at: https://www.gov.uk/government/publications/reviewinto-the-exclusion-of-women-from-ground-close-combat-roles-terms-of-reference [Accessed 17 Mar. 2016].

Nagel, T. [1972] 1979 "War and Massacre" in Mortal Questions. Cambridge: Cambridge University Press, pp. 53-74. 
Skeggs, B. 2005. "The Making of Class and Gender through Visualizing Moral Subject Formation" Sociology (December 39): 965-982, doi:10.1177/0038038505058381. [Accessed 17 Mar. 2016].

Sex Discrimination Act 1975 Available at http://www.legislation.gov.uk/ukpga/1975/65/enacted [Accessed 4 April 2016]

Wollaston, S. 2013 "Foyle's War; Our Girl - TV Review" Guardian. Available at: http://www.theguardian.com/tv-and-radio/tvandradioblog/2013/mar/25/foyles-war-our-girltv-review [Accessed 17 Mar. 2016].

\section{Filmography}

The Bells Go Down 1943. (dir. Basil Dearden, Ealing Studios).

The Way Ahead 1944. (dir. Carol Read. Two Cities Films)

The Blue Lamp. 1950. (Dir. Basil Dearden. Arthur Rank and Earling Studios)

\section{TV shows}

Our Girl BBC 2014, script Tony Grounds, dir. David Drury, Anthony Phillipson, Richard Senior

Soldier, Soldier Central 1991-97

Downton Abbey, ITV 1997 - 2015 script Julian Fellowes, Shelagh Stephenson and Tina Peplar, dir. Brian Percival et al

War and Peace BBC 2015, script Andrew Davies; dir. Tom Harper

\footnotetext{
${ }^{1}$ Despite the illegality of sex discrimination in the workplace, the United Kingdom does not currently allow women in the army to participate in front line combat, although instances of such activity with women medics deployed to Afghanistan has been reported. This discrimination is "legally" allowed due to an exemption in the United Kingdom legislation, Section 85(4) the Sex Discrimination Act 1975 (SDA 75), on the grounds of
} 
"ensuring the combat effectiveness of the Armed Forces". Another gender discrimination is made in Schedule 3 , Part 1, para 4 of the Equality Act 2010, which allows "women to be excluded from those posts where the military judgement is that the employment of women would undermine and degrade combat effectiveness" (Ministry of Defence 2014).

2 In John Major's 1991 address, his first speech as Tory leader, he proclaimed "I spoke of a classless society. I don't shrink from that phrase. I don't mean a society in which everyone is the same, or thinks the same, or earns the same. But a tapestry of talents in which everyone from child to adult respects achievement; where every promotion, every certificate is respected; and each person's contribution is valued. And where the greatest respect is reserved for the law."

3 Just before the general election in 1997, Prescott famously announced that "we're all middle class now". This was widely interpreted as an attempt to sum up Tony Blair's 'Big Tent' politics; a claimed accommodation of differing political views and approaches 